\title{
SenseMarcia: O humor e a religiosidade esotérica na ambiência da sociedade midiatizada $^{1}$
}

\section{Francys Albrecht da Rosa}

Universidade Federal de Santa Maria, Departamento de Ciências da Comunicação, Santa Maria, RS, Brasil ORCID: https://orcid.org/0000-0003-2866-3925

\section{Aline Roes Dalmolin}

Universidade Federal de Santa Maria, Departamento de Ciências da Comunicação, Santa Maria, RS, Brasil ORCID: https://orcid.org/0000-0003-4413-0061

\section{Resumo}

Este trabalho se propõe a analisar o entrelaçamento entre conteúdo humorístico e religioso no canal do Youtube SenseMarcia com o objetivo de identificar quais são as estratégias utilizadas, pelo canal SenseMarcia, para criar conotações de humor ao conteúdo religioso midiatizado criado pela astróloga Márcia Fernandes. Para realizar a pesquisa, como aporte teórico, foram referenciados os autores Hjarvard (2014) e Sbardelotto (2017) para dar conta da noção de midiatização, Hervieu-Léger (2008) para conceituação de secularização e para análise metodológica de três vídeos, por meio da análise de conteúdo em conjunto com as proposições de categorias de humor de Figueiredo (2012). No decorrer do desenvolvimento da pesquisa, foi observado que distintas menções religiosas e terapêuticas são utilizadas pelos proprietários do canal que realizam uma fusão de referências midiáticas, combinando mídias e diferentes assuntos para compor suas estratégias de conferir efeito humorístico.

\section{Palavras-chave}

Humor. Midiatização. Religião. Esoterismo. Multiplataformas.

\section{Introdução}

Essa pesquisa se propõe a lançar um olhar sobre o entrelaçamento existente entre humor e religiosidade no canal SenseMarcia (2016) no Youtube. Primeiramente, é pertinente que conheçamos o objeto. Márcia Fernandes é terapeuta holística e estuda

\footnotetext{
${ }^{1}$ Uma versão preliminar foi apresentada e consta nos Anais do II Simpósio Internacional de Comunicação, Frederico Westphalen, em 2018.
} 
espiritualidade há mais de 40 anos (MARCIA..., 2018), ela afirma ser batizada como católica e seguir o kardecismo. Além disto, denomina-se como especialista em astrologia, numerologia e mestre em reiki, incluindo, também, elementos das religiões afrobrasileiras, como banho de ervas, nas suas técnicas. A terapeuta ficou conhecida no país por participar de programas televisivos vespertinos de diferentes emissoras para falar sobre assuntos religiosos como, por exemplo, rituais para atrair prosperidade na virada do ano e previsões astrológicas para cada signo. Entretanto, o canal do Youtube que será analisado não pertence à astróloga e trata-se de um espaço onde são publicados vídeos humorísticos que contêm recortes de imagens e áudios de Márcia retirados da internet, como programas gravados em rádios ou entrevistas televisivas, e também do seu canal oficial.

O canal SenseMarcia (2016) existe desde 2016 e possui, atualmente, mais 20 mil inscritos. Os vídeos, em geral, são curtos e não chegam a um minuto de duração. 0 conteúdo do canal é diversificado e brinca ao sobrepor imagens e áudios de Márcia a outros vídeos, como virais da internet, cenas de filmes ou cenas de programas que a própria terapeuta participou, muitas vezes, fazendo alguma correlação com um assunto que está em pauta no momento da publicação.

Figura 1 - Canal SenseMarcia

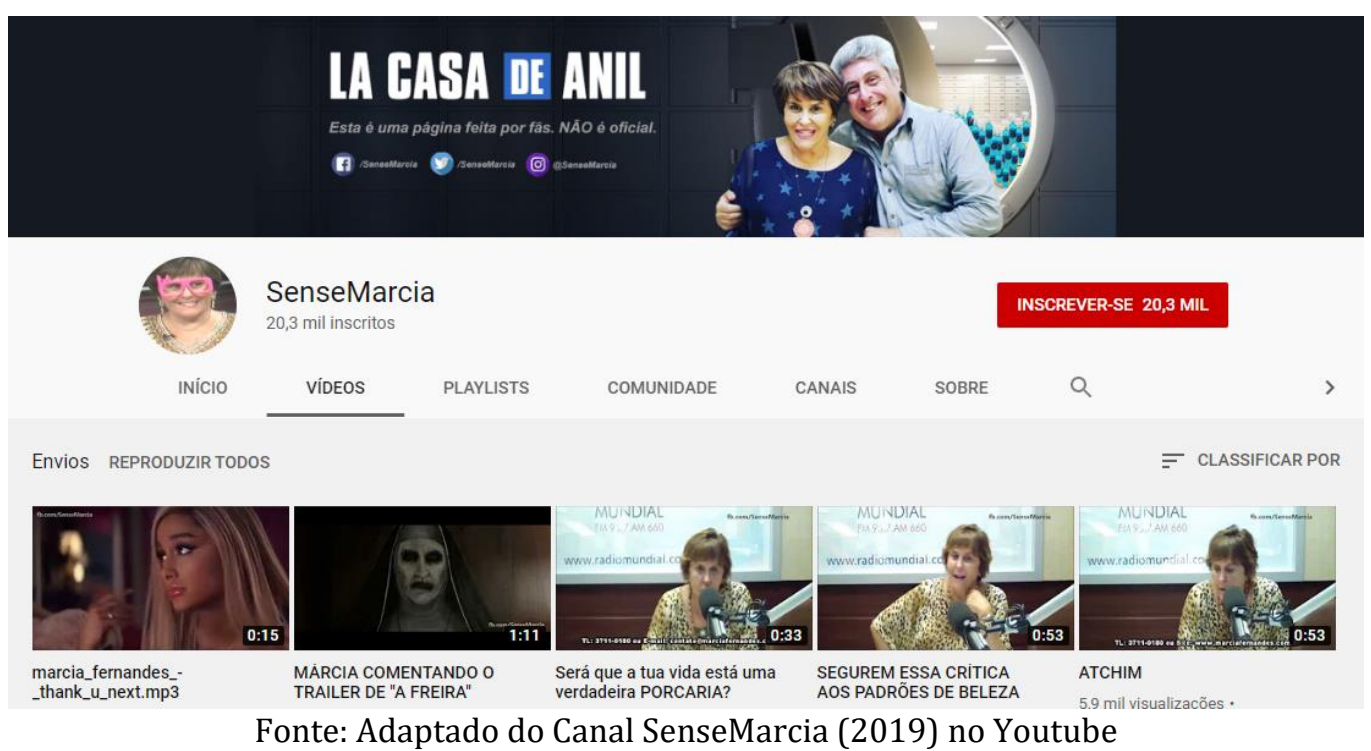

Tendo isto em mente, este trabalho busca responder: quais são as estratégias utilizadas, pelo canal SenseMarcia (2016) para criar conotações de humor ao conteúdo religioso midiatizado criado pela astróloga Márcia Fernandes? Para que seja possível 
responder esta questão, é necessário que seja composto um quadro que irá fundamentar teoricamente a pesquisa. Dessa forma, esta investigação será dividida em cinco tópicos: no primeiro, a introdução; no segundo, serão expostos conceitos e fundamentos da teoria da midiatização da sociedade; em um terceiro momento, será feita uma discussão a respeito do lugar das crenças na ambiência secularizada; em quarto, serão expostas algumas categorizações de humor que auxiliarão na fundamentação teórica da metodologia a ser aplicada, por último, à análise dos vídeos.

No tocante à midiatização, compreende-se enquanto um processo social de produção de sentido (HJARVARD, 2014) que é resultante das transformações ocasionadas pelo desenvolvimento da modernidade. As posições dos interagentes são alteradas no processo de comunicação mediada - as polarizadas instâncias produtora e receptora, atualmente, são insuficientes para descrever o ato comunicacional, visto que ambas ocupam mutuamente as duas funções. Tendo em mente que, não apenas os papeis dos indivíduos são alterados, como também aqueles desempenhados pelas instituições, é pertinente afirmar que o contexto social se torna, gradualmente, dependente e perpassado pela instância midiática. A mídia, por sua vez, adquire um caráter institucional e passa a mediar outros processos que, anteriormente, não eram da sua competência. Como exemplo disso, destaca-se o campo religioso, perpassado intensamente pela lógica da mídia (SBARDELOTTO, 2017), a ponto de alterar suas práticas, rituais e modalidades de fé para se adequar à ambiência midiatizada. Logo, faz-se necessário investigar não apenas a presença das religiões na mídia, mas a forma como a mídia interfere, reconfigura e transita no ambiente religioso.

A segunda vertente teórica diz respeito à discussão sobre a secularização do Estado proposta por Hervieu-Léger (2008). Para a autora, o Estado secular não é sinônimo do desaparecimento da religião, senão um movimento de menor regulação, perda do poder de coerção sobre os fiéis e diminuição da ação e domínio institucional religioso (HERVIEULÉGER, 2008). A religião, dessa forma, não é obliterada do mundo moderno, mas surge sob novas configurações que lhe permitem ter maior aceitação social diante dos avanços ocidentais adquiridos como tecnologia, avanço científico, direitos civis, trocas culturais e racionalização das práticas coletivas.

A terceira elaboração teórica desta pesquisa destina-se à construção metodológica. Primeiramente, serão expostos os conceitos que embasam a teoria do humor por Figueiredo (2012): a teoria da superioridade que parte do princípio de que rimos daquilo que não nos toca, pois não temos sentimentos sobre o objeto; a teoria do alívio que se trata da tensão 
presente no clímax da interação; a teoria da incongruência, que consiste na quebra de expectativa, um fim inesperado. Baseando-se nesses três pressupostos que têm por objetivo encontrar a razão pela qual rimos, estes conceitos serão aplicados à seleção de uma mostra de vídeos baseada na análise de conteúdo.

Por último, partimos à seção analítica que, por meio da metodologia adotada, em união à discussão teórica elaborada no início deste artigo, pretende responder à questão norteadora desta pesquisa. Assim sendo, serão analisados três vídeos do canal SenseMarcia para que possamos compreender de que forma se dá o compartilhamento de conteúdo humorístico sobre religião na sociedade em midiatização.

\section{Midiatização: uma transformação social}

No meio acadêmico do campo da comunicação, muito se ouve falar sobre midiatização, entretanto, há um certo uso indiscriminado do termo que pode comprometer a autenticidade e relevância desta perspectiva teórica. Isto posto, a intenção desta sessão é propor uma síntese do que vem a ser a midiatização e quais os reflexos que este fenômeno técnico-discursivo produz na sociedade. Além disso, busca-se direcionar a discussão para um tópico específico: lançar olhar sobre a produção religiosa de sentidos midiatizados.

Para iniciar este percurso, parte-se da ideia de que a midiatização é uma proposição teórica que permite compreender a produção de sentidos de forma coletiva. Segundo Mata (1999), o conceito de sociedade midiatizada surge para explicar o que as antigas proposições já não davam conta, como por exemplo, a mídia massiva. Para a autora,

Essa insuficiência não se deve apenas às transformações materiais nos modos de produção cultural, mas também a uma transformação dos pontos de vista adotados para a análise da comunicação e da cultura (MATA, 1999, p. 81, tradução nossa)2.

A globalização desempenha um importante papel neste sentido, visto que é responsável por muitas transformações que ainda ocorrem no seio da sociedade. As fronteiras, por exemplo, tornam-se mais fluidas, de modo que a mídia pôde transitar também por territórios que, anteriormente, não eram de seu domínio (como a religião, por exemplo). Desta forma, as

\footnotetext{
2 No original: "Esa insuficiência no sólo se debía a transformaciones materiales en los modos de producción cultural, sino a una transformación de los puntos de vista adoptados para el análisis de la comunicación y la cultura".
} 
práticas midiáticas fazem uso deste trânsito com menos barreiras entre campos sociais, onde as culturas tornam-se mais abertas para intercâmbios e há um crescimento da comercialização e consumo midiático e, consequentemente, há espaço para transformações socioculturais.

Hjarvard (2014) busca conceituar o processo de midiatização que vem se instaurando na sociedade enquanto o momento em que a mídia passa a transmitir suas lógicas de funcionamento para as outras instituições. Dessa forma, este novo lugar de destaque que vem sendo ocupado pela mídia na contemporaneidade pressupõe uma racionalidade institucional diferente da que víamos no passado. As instituições aos poucos perdem seu rígido domínio de um aspecto da vida social, ao passo que a dependência dos recursos midiáticos aumenta. 0 que se nota, portanto, é uma hibridização da vida e da organização social transbordada pela mídia.

Nesse sentido, as práticas institucionalizadas pelas instâncias midiáticas passam a influenciar cada vez mais outras esferas. Essa influência, segundo Hjarvard (2014), se deve à capacidade da mídia em construir uma realidade calcada na credibilidade que o público deposita nela. 0 autor afirma que "Vivemos uma midiatização intensiva da cultura e da sociedade que não se limita à formação da opinião pública, mas atravessa quase todas as instituições sociais e culturais" (HJARVARD, 2014, p. 21). Ele é enfático ao afirmar que a midiatização corresponde aos processos contemporâneos nos quais a cultura, instituições e a sociedade se tornam dependentes dos meios de comunicação e passam a operar com base no fazer midiático.

0 processo de midiatização, sendo assim, é resultado da racionalização do mundo ocidental, assim como a divisão do trabalho, industrialização, êxodo rural e, por fim, a cultura do individualismo. Esse dinâmica da modernidade causaria um desencaixe no tempo-espaço que teria influência direta nas práticas sociais modificadas, realocadas e abstratizadas. Assim como podemos notar no excerto,

A mídia de massa e a mídia de rede social, igualmente, oferecem um constante fluxo de informação que orienta os indivíduos e as organizações para reajustar suas práticas às condições contemporâneas, dessa forma implantando uma reflexividade progressiva na própria institucionalização da vida social. (HJARVARD, 2014, p. 30). 
Nesta gama de modificações sociais, a religião vem sendo afetada desde o marco do iluminismo, que representa a passagem para o pensamento racional ocidental. Da mesma forma, na contemporaneidade, as instituições religiosas encontraram nos fluxos midiáticos e nas suas novas formas de articulação uma maneira distinta de entrar em contato com os fiéis, remodelando as práticas e os rituais para uma realidade midiatizada.

Sbardelotto (2017) concebe a midiatização como um desdobramento da internet que é responsável por diversas transformações sociais em razão das novas possibilidades de construção de sentido. Na sociedade midiatizada, não há mais posições demarcadas de produção e recepção, e aqueles que não detinham o domínio dos meios técnicos de transmissão de informação agora possuem uma determinada capacidade de agência nesse tecido social digital que se constrói. Para o autor, essa possibilidade de agência gera uma autonomia dos sujeitos, que podem readaptar os significados midiáticos, não estando tão dependentes de uma instância produtora que lhe outorgue sentidos (SBARDELOTTO, 2017).

Essa característica da midiatização em possibilitar novar formas de interação, visto que inclusive a posição dos sujeitos no ato comunicativo foi alterada, promove resultados que afetam o funcionamento de instituições como a religião. As religiões se veem diretamente impactadas, pois há uma crescente ressignificação do que é sagrado, do ser fiel e da experiência religiosa. Nesse sentido, Sbardelotto (2017) afirma que é necessário compreender esta situação complexa que se põe diante de nós, visto que há uma forte articulação entre as lógicas da mídia apropriadas pela religião. Sendo assim, faz-se necessário estudar não só a presença da religião nas mídias, mas também a presença das mídias na prática religiosa.

Ao estudar uma crença na contemporaneidade, deve-se levar em consideração as complexificações existentes da relação entre religião e as lógicas midiáticas. Dessa forma, Sbardelotto (2017) chama esse processo de "midiamorfose da fé". Esse fenômeno é observado não apenas em instituições religiosas consagradas como o catolicismo ou as igrejas neopentecostais - tão presentes no ambiente midiático brasileiro - mas também em novas configurações de religiosidade, como o canal no Youtube SenseMarcia, que divulga um conteúdo que une humor e religiosidade, pensando práticas midiáticas, observando as tendências e atento às lógicas de interação da plataforma.

Devido a essa nova possibilidade de produção de sentidos, segundo Sbardelotto (2017), faz-se necessário, nos estudos de midiatização da religião, romper com a dicotomia funcional do uso da mídia pela religião, visto que tanto o midiático como o religioso são 
formas transcendentes de interação e ambas instâncias são perpassadas fortemente por uma carga simbólica. A mídia, enquanto instrumento de interação com o mundo, desde as pinturas rupestres até a era digital, vai além da interação face a face. É possível afirmar que estabelece uma relação mediada, que transcende o tempo e o espaço, como as pinturas nas cavernas que até hoje nos comunicam sentidos, como a internet que supre a distância geográfica. A religião, da mesma forma, é um ato interativo com o divino, com o extraterreno.

Acredita-se, portanto, que seja essa a interface que faz a conexão entre mídia e religião, sendo as duas uma resposta às necessidades socioculturais de comunicação que, na atualidade, fundem-se tendo em vista que o modo como nos comunicamos transformou-se com o avanço da tecnologia e da modernidade, bem como a religião também não permanece imutável, mas se rearranja para manter-se em vigência nesse processo de midiatização.

\section{Crenças secularizadas}

A discussão sobre uma sociologia da religião para esta pesquisa vai ao encontro da perspectiva de (des)secularização do Estado proposta por Hervieu-Léger (2008). Para a autora, a secularização não é sinônimo de menos religião, e sim de menos regulação institucional por parte das instituições religiosas (HERVIEU-LÉGER, 2008). A religião não perde espaço no mundo moderno, entretanto, surge sob novas configurações que lhe permitem ter maior aceitação social e praticabilidade da fé diante dos inúmeros avanços ocidentais como desenvolvimento tecnológico e científico, direitos civis, estrutura da família, organização social do trabalho e mudanças culturais potencializadas, especialmente, pela globalização.

Vale relembrar que, até o fim da Idade Média, a igreja compunha a instituição que detinha o poder de organização, coesão e coação social, além de ocupar a função de guia espiritual, ou seja, ordenava as vidas na terra e preparava os sujeitos para o encontro com o divino. A mudança dessa estrutura ocorreu na medida em que a modernidade avançava e surgia a necessidade de o Estado se distinguir da religião, sobretudo pela influência racionalista - a razão no centro de tudo - que orientou não só o pensamento cientifico, como toda a sociedade. É nesse ponto que há uma bifurcação do conceito de secularização: o primeiro compreende como o fim da religião, e o segundo, que iremos adotar nesse trabalho, é de que foi o responsável pelo surgimento de novos movimentos religiosos. Nesse cenário 
de alta racionalização das técnicas de trabalho, das formas de vida, dos problemas causados pela própria modernidade e o afastamento dos sujeitos de sua essência sensível é que emergem movimentos religiosos flutuantes.

Nesse sentido, a secularização não é sinônimo de apagamento da atuação das religiões, pelo contrário, ela propulsiona que novas formas de crença surjam, cada vez mais subjetivas, individualizadas e sem caráter institucional (HERVIEU-LÉGER, 2008). Isso se deve ao fato de que a razão que norteia a contemporaneidade suscita muito mais perguntas do que disponibiliza respostas acerca da existência humana. Devido a esta característica, é possível perceber uma crescente incontingência da sociedade, marcada pelas dúvidas, medos e inseguranças. $\mathrm{O}$ acalento e a certeza, anteriormente provido pelos ensinamentos religiosos, de um futuro extraterreno que compensaria as agruras da vida, perdem a força e ausência de explicações sobre o devir torna-se um dos motivos para emergência de novas formas de religiosidade que compensem a carência existencial e espiritual, sem que comprometam a liberdade e os avanços conquistados pela modernidade.

Giddens (2002) é um dos autores que se dedicou a compreender como os reflexos da modernidade nos atravessam, interagem, modificam e são cruciais na formação de nossa identidade. Devido ao fato de vivermos em uma sociedade globalizada, as referências culturais e religiosas são abundantes e cabe a cada indivíduo ir em busca daqueles elementos que mais lhe representam. A multiplicidade de escolhas era concebida como um ato de liberdade em um contexto onde a tradição e o conservadorismo eram reinantes. Entretanto, a atualidade é marcada por uma fluidez e multiplicidade de escolhas que proporcionam maior liberdade aos indivíduos e, ao mesmo tempo, ansiedade, visto que os sujeitos não possuem mais certezas de que as escolhas que fazem são as mais apropriadas. É essa insegurança ontológica (GIDDENS, 2002) que marca nossas identidades modernas e é uma explicação para o surgimento de tantos produtos de autoajuda, esoterismo, guias espirituais e grupos religiosos.

É neste contexto que Hervieu-Léger (2008) propõe o conceito de bricolagem - este consiste no recorte de especificidades de diferentes movimentos religiosos para compor a sua crença, única, personalizada e que se adeque as suas necessidades e expectativas. Essa bricolagem surge como uma nova possibilidade do crer na sociedade pós-moderna, que se adeque aos diferentes fluxos culturais, sociais e econômicos pelos quais somos atravessados diariamente e que incitam uma construção e reconstrução das nossas identificações. 
Nessas novas formulações da crença, há uma transferência de foco do sagrado para o sujeito. Devido à ideologia político-econômica neoliberal, marcada pela radicalização do individualismo, os sujeitos são responsabilizados pelo gerenciamento das suas próprias necessidades e existência. Sendo assim, uma instituição agregadora como a igreja, por exemplo, não representa mais a ordenação social. Atualmente, é a faculdade racional e individual de cada pessoa que o torna responsável por construir para si o próprio mundo, inclusive, sua crença.

Neste ambiente em que o sujeito é impelido a assumir total controle sobre sua vida, parece coerente que ele mesmo construa sua religião de acordo com os objetos simbólicos que mais lhes satisfaçam. Cada pessoa, focada em si mesma, busca por felicidade, sucesso, prosperidade e crescimento pessoal por meio de diferentes artifícios. Entre as ferramentas disponíveis, está a crença, cada vez mais personalizada e disponível por diferentes meios, muitas vezes, não religiosos. É neste momento em que a mídia e a religião se encontram, pois não se faz necessário frequentar uma igreja, um centro espírita ou casa de umbanda para experimentar a fé. Através dos meios técnico-discursivos, como redes sociais, aplicativos de mensagens, plataformas de vídeo, missas são transmitidas ao vivo, canais religiosos na televisão aberta e privada são cada vez mais comuns, da mesma forma que é possível fazer simpatias ensinadas em sites, cantar pontos de divindades africanas hospedados no Youtube, compartilhar experiências e estreitar laços com fiéis da mesma crença por meio das comunidades virtuais.

A bricolagem proposta por Hervieu-Léger (2008) representa esse momento histórico em que a crença não atende a vontade última da cosmovisão de cada religião, pois a crença torna-se cada vez mais personalizável. As religiões, para não perderem adeptos, modificam suas estratégias de proselitismo e transcendência de rituais. 0 uso das ferramentas midiáticas auxilia desde a captação de novos fiéis, como também na execução dos ritos e transmissão do simbólico. Assim sendo, a religião continua presente na vida pósmoderna, entretanto, reconfigurada às lógicas da mídia, pois a instituição midiática, junto à tecnologia, está transformando a experiência do viver na contemporaneidade.

\section{0 humor religioso midiatizado}

Estudar humor é contar com poucas fontes teóricas que expliquem o fenômeno do rir e achar graça, sobretudo, no campo da comunicação. Para tanto, é necessário aventurar- 
se por autores que se distanciam da linguagem médica ou neurociência, e analisam pela perspectiva da psicanálise, psicologia, sociologia e antropologia. Entre as perspectivas, a divergência mais evidente centra-se na concepção de que o riso é apenas um mecanismo físico de estímulos puramente fisiológicos em contraponto à ideia de que o riso é uma reação consciente que denota a inteligência, além de ser um aspecto de diferenciação entre o cérebro humano e de outros animais. A pesar dos desacordos, há um ponto em comum: o ser humano é o único animal capaz de rir.

Segundo Bergson (1978), rir é um ato simbólico coletivo, pois o humor é intrinsecamente social. Para que algo seja engraçado, ele precisa ser reconhecido por um grupo de pessoas, visto que se individualizarmos o objeto do riso, ele não fará sentido para os outros. Tendo isto em mente, é importante compreendermos que o canal humorístico SenseMarcia (2016), no Youtube, é voltado para um público que já conhece a astróloga Márcia Fernandes e é interessado ou praticante de terapias holísticas. A terapeuta desperta interesse do público pela sua personalidade e comportamento que destoam do estereótipo criado em torno de pessoas adeptas às crenças orientais como a serenidade, tom de voz tranquilo, apego ao lado positivo da vida, bem como porta-vozes de mensagens edificantes acerca de prosperidade e autoconhecimento. Fernandes tem uma personalidade explosiva, extrovertida, fala alto, responde os ouvintes do seu programa radiofônico ou telespectadores com certa rispidez e, muitas vezes, com tom de pessimismo ou más previsões acerca do futuro, baseando-se na leitura de cartas, numerologia ou astrologia.

Dessa forma, o canal SenseMarcia (2016) publica o conteúdo para aqueles que já possuem esse conhecimento prévio, pois estes possuem condições de compreender as conexões realizadas entre o comportamento de Fernandes, as diferentes menções religiosas, bem como as referências de paródias, memes e outros recursos midiáticos utilizados para completar a intenção da mensagem - fazer os seguidores rirem.

Segundo Figueiredo (2012), dentre os estudos sobre o riso, existem algumas categorias que podem explicar o funcionamento do humor: a teoria da superioridade, do alívio e da incongruência. A teoria da superioridade (FIGUEIREDO, 2012) é basicamente calcada na máxima de que rimos porque nos sentimos soberanos aqueles que nos são motivos de riso. 0 humor seria um subterfúgio para tornar aceitável o sentimento de superioridade sobre algo ou alguém. A gargalhada seria o eufemismo de uma intenção maldosa, ou seja, rir traria leveza a um assunto pesado, principalmente, quando tratado com descaso. Na teoria da superioridade, rimos porque não fazemos parte daqueles que estão 
sendo objetos de riso. 0 oposto a esse comportamento é a preocupação e a pena. 0 riso não faz sentido e não se encaixa entre esses sentimentos e, caso ocorra, estará atrelado às sensações de remorso e pela culpa.

O alívio, por sua vez, é concebido na tensão do diálogo, no desenrolar da conversação entre os interlocutores. Apresenta-se como uma válvula de escape que libera toda uma tensão presente na interação entre dois sujeitos, "o riso será proporcional à tensão gerada", afirma Figueiredo (2012, p. 183). E, por fim, a teoria da incongruência está atrelada à quebra de expectativas ou do fluxo narrativo, ela pode ser verbal ou visual e causa riso por ser um desfecho inesperado, devido uma abrupta mudança de raciocínio causada nos sujeitos.

Outra notável característica do humor é a de que rimos apenas daquilo que nos remete à figura humana. É possível encontrar inúmeros exemplos de virais que caem na graça do público, como cachorros que parecem balbuciar palavras ou com as patas sobre o piano, gatos e papagaios que são adotados por empresas e recebem crachá de funcionários das mesmas ou, então, cabras, galinhas e outros animais utilizando roupas que imitiam trajes formais. Não só o que imita o humano é capaz de despertar o riso, como também o que demonstra uma falha humana, como por exemplo, a falha de comunicação entre duas pessoas ou tombos. Prova disto, são canais do Youtube e páginas de redes sociais destinadas apenas a este tipo de conteúdo, como o FailArmy (2011), que possui mais de 14 milhões de inscritos de diversos países, e é responsável pela publicação de vídeos de pessoas que riem dos próprios erros e não se levam tão a sério, como afirma a descrição do mesmo. A deformidade, dessa forma, também tem a competência de provocar o riso, especialmente se esse defeito puder ser imitado. Por exemplo, o andar estereotipado de um idoso é um recurso utilizado para interpretar personagens mais velhos e, dependendo do nível caricato, poderá ser motivo de riso.

Levando em consideração o momento histórico em que nos encontramos, marcado pela midiatização da sociedade, é possível afirmar que desde a mídia radiofônica, impressa e massiva havia um espaço dedicado ao humor na grade de programação, por meio das novelas, dos cartoons, dos programas humorísticos de auditório, entre outros. Nas mídias virtuais, devido à imensa variedade e oferta, é perceptível o surgimento de conteúdos por nichos, mais específicos, mas que não deixam de ter grande alcance e repercussão como é o caso de humor e religiosidade do objeto de investigação SenseMarcia (2016). Na seção a seguir, será desenvolvida a metodologia utilizada para a análise de uma amostra vídeos do canal, bem como o momento em que a discussão teórica desenvolvida até aqui - as 
categorias de humor já citadas, em consonância com a teoria da midiatização e bricolagem religiosa - possa encontrar o objeto.

\section{Senso de humor no canal Sensemarcia}

Tendo em mente que o objeto desta pesquisa é investigar quais são as estratégias utilizadas pelo canal SenseMarcia para criar conotações de humor ao conteúdo religioso midiatizado criado pela astróloga Márcia Fernandes, opta-se pela abordagem da análise de conteúdo. Dessa forma, após uma exposição quantitativa de dados, a dimensão qualitativa é encarregada de tecer inferências que possibilitem compreendem um aspecto da realidade social a partir do objeto investigado.

Para Assman, Quadros e Lopez (2014) a análise de conteúdo “[...]tem como objetos produtos midiáticos servindo como ferramenta auxiliar na compreensão de fenômenos sociais, a partir do que é registrado pelos meios de comunicação" (LOPEZ; ASSMAN; QUADROS, 2014, p. 89). Isto posto, se pegarmos como referência o Youtube, plataforma que hospeda os vídeos do canal SenseMarcia (2016), bem como as mídias massivas rádio e televisão onde a astróloga concede entrevistas e participa ativamente, já possuímos essas ferramentas de mídia que dão conta de registrar, produzir, replicar e compartilhar conteúdos que envolvem tanto a dimensão religiosa quanto humorística. Essa ambiência de multiplataformas e usos diversificados das mesmas é reflexo do fenômeno social de midiatização (HJARVARD, 2014), em que a produção de sentidos extrapola a competência dos profissionais de comunicação, e os consumidores são também produtores. 0 canal SenseMarcia (2016), portanto, caracteriza-se por ser um produto intrinsecamente midiatizado, exatamente por estar hospedado nas mídias digitais e ser produzido por seguidores da terapeuta holística Márcia Fernandes que, em outro momento, estariam fadados apenas à função de receptores.

O canal surgiu em 2016, portanto, os vídeos mais antigos são de três anos atrás (SENSEMARCIA, 2016). Ao total, são 515 vídeos publicados, e o mais recente é de fevereiro de 2019 (SENSEMARCIA, 2016). Tendo em vista que, devido à limitação de caracteres para um artigo científico, a análise deste estudo será sobre uma amostra de três vídeos. A escolha destes deve-se a três critérios: são paródias ou sobreposição de imagens de outras mídias, como videoclipes, virais da internet ou programas televisivos junto a imagens ou áudios de Márcia Fernandes; possuem mais de uma referência religiosa; e utilizam recursos de sons e 
imagens diferentes para conferir uma unidade de sentido, como por exemplo, fragmento da fala de um personagem de um desenho animado sendo acoplado a um áudio de Fernandes.

Para tanto, serão descritos os vídeos, bem como extraídos excertos discursivos a serem analisados à luz das estratégias que concedem conotações de humor trabalhadas por Figueiredo (2012) em conjunto com os conceitos abordados, anteriormente, no corpo teórico deste estudo. Como é possível observar, o próprio nome do canal faz referência à mediunidade e sensitividade que Márcia Fernandes afirma possuir, além de ser uma paródia do nome do seriado norte-americano Sense8 ${ }^{3}$, mais uma demonstração de como o canal faz uma mescla de referências sobre assuntos atuais como, por exemplo, seriados populares eassuntos religiosos, e utiliza diferentes mídias para compor o conteúdo do canal no Youtube.

O primeiro vídeo analisado chama-se Por essa visão a Raven não esperava (2017). As Visões da Raven é um seriado norte-americano do início dos anos 2000 que conta a história de uma adolescente, Raven, que tem visões, déjà vu sobre o futuro. 0 canal SenseMarcia (2016) fez um recorte de uma cena do seriado que mostra a protagonista Raven em frente a uma bola de cristal fazendo atendimento espiritual e, aos três segundos, diz "Senhorita Talula na linha para desvendar o seu futuro. A próxima chamada, quem é você?" (POR..., 2017, doc. não paginado). Nesse instante, surge a voz de uma ouvinte do programa radiofônico de Márcia Fernandes que pergunta sobre o amor, então surge a imagem da astróloga Márcia, em tons de sépia, simulando uma visão de Raven e revela, aos 15 segundos, “Ai Rosangela, desculpa tá? Mas eu não vejo nada de amor nos próximos dois anos.". E, por fim, a imagem retorna para a cena do seriado antes de terminar o vídeo (POR.., 2017).

\footnotetext{
30 seriado conta a história de 8 pessoas que vivem em diferentes lugares do mundo e que podem se comunicar, ver e tocar por poderes telepáticos, sem que haja uma presença física real.
} 
Figura 2 - Vídeo Por essa visão a Raven não esperava (2017)

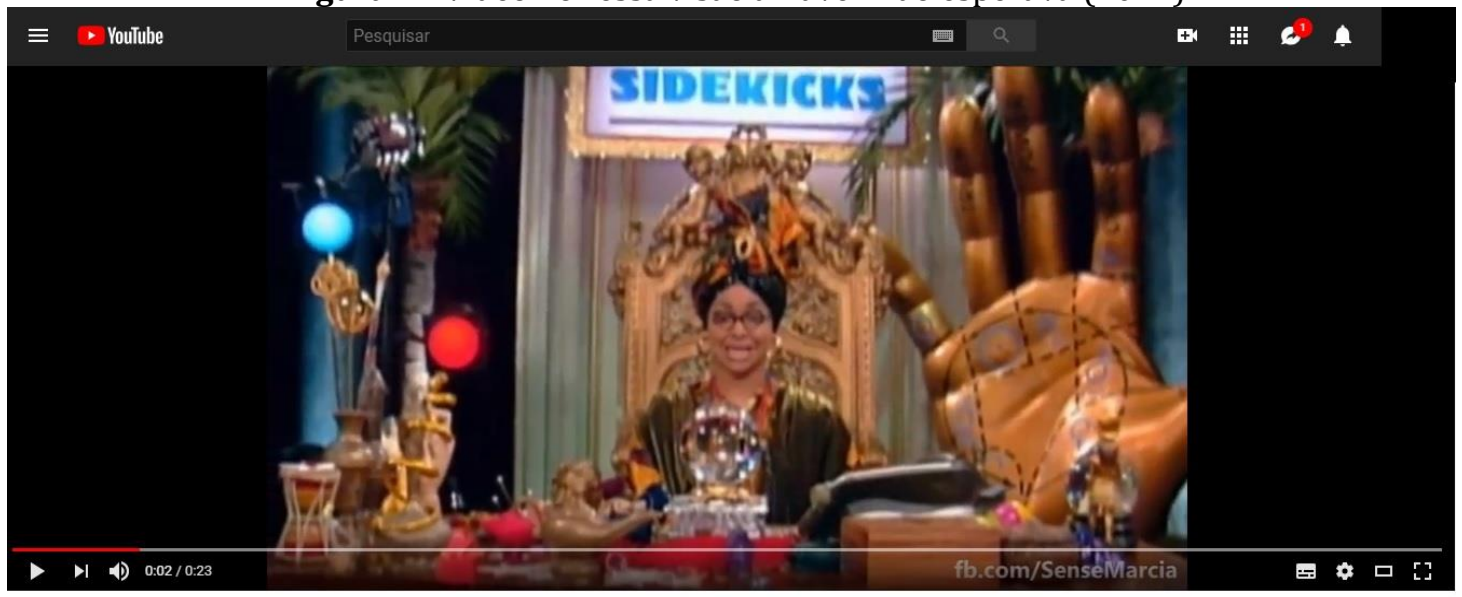

POR ESSA VISÃO A RAVEN NÃO ESPERAVA

677 visualizações

Fonte: Adaptado do canal SenseMarcia (2016) no Youtube.

Neste exemplo, é possível notar as múltiplas possibilidades de produção de sentido na ambiência midiatizada (HJARVARD, 2014). Um canal no Youtube, para produzir seu conteúdo, fez referências e recortes da mídia televisiva norte-americana e de um programa radiofônico brasileiro sobre assuntos espirituais. A montagem do vídeo nos leva a uma leitura única, onde os sentidos produzidos, em cada uma das mídias, parecem conversar e fazer parte de um único assunto.

O vídeo também elucida as estratégias empregadas para a produção do humor. 0 seriado As Visões de Raven é do gênero comédia, portanto, quem assiste o vídeo (POR..., 2017) e conhece a referência já percebe que a montagem do vídeo se trata de uma piada. A técnica utilizada para despertar o tom humorístico é, segundo Figueiredo (2012) a quebra de raciocínio, pois o interlocutor assiste o vídeo que inicia com imagens do seriado e é surpreendido pela quebra de ritmo, o corte de imagem para o programa de Márcia Fernandes. Há também uma quebra de expectativas no sentido de que há uma intenção de busca por respostas e consolo nas religiões, entretanto, a pessoa que liga com interesse sobre seu futuro amoroso acaba recebendo apenas notícias ruins.

Essa característica do programa de rádio da astróloga Márcia Fernandes receber muitas ligações em busca orientações para o futuro, seja profissional, amoroso, espiritual ou financeiro demarca a insegurança da vida na alta modernidade. Assim como Hervieu-Léger (2008) aponta a racionalidade do pensamento científico ocidental como um propulsor de novas religiões e não o exterminador delas, Giddens (2002) corrobora a ideia de vivermos 
com carência de refúgio, o que torna grupos religiosos, entidades místicas e autoajuda um porto seguro, um direcionamento, uma certeza em um mar de escolhas e caminhos a serem seguidos.

O segundo vídeo a ser analisado é SenseMarcia chamando os cachorros (2017). Durante todos os 39 segundos, são mostradas as imagens de um viral (DOG..., 2017) que circulou pela web, na qual dez cães esperam, comportadamente, que sua dona os chame pelos seus respectivos nomes, estando, assim, permitidos para subir as escadas e entrar na casa. Entretanto, o vídeo que compõe o corpus desta pesquisa é uma paródia em que o áudio original é substituído por fragmentos de falas da terapeuta holística Márcia Fernandes. Vale ressaltar que o vídeo original, de acordo com Figueiredo (2012), desperta sentidos de humor devido à humanização dos animais, visto que, segundo o autor, rimos daquilo que se parece com nossa humanidade. Dessa forma, observarmos animais que atendem aos seus nomes tais como as pessoas pode ser engraçado, e supomos que seja este um dos motivos do mesmo ter alcançado grande repercussão.

Aos cinco segundos temos a imagem dos cachorros à espera de serem chamados, quando ouvimos um recorte da voz de Márcia dizendo "geminiana, filha de Cosme e Damião"4 (SENSEMARCIA..., 2017, doc. não paginado) em consonância com um dos cães subindo as escadas, como se atendesse ao seu nome. Esta estratégia em substituir o áudio original causa uma unidade de sentido e, mesmo se tratando de assuntos diferentes, ainda possui a capacidade comunicativa e de transmissão de mensagens, dessa vez, com mais sentidos e possíveis significados agregados.

Figura 3 - Vídeo SenseMarcia chamando os cachorros (2017)

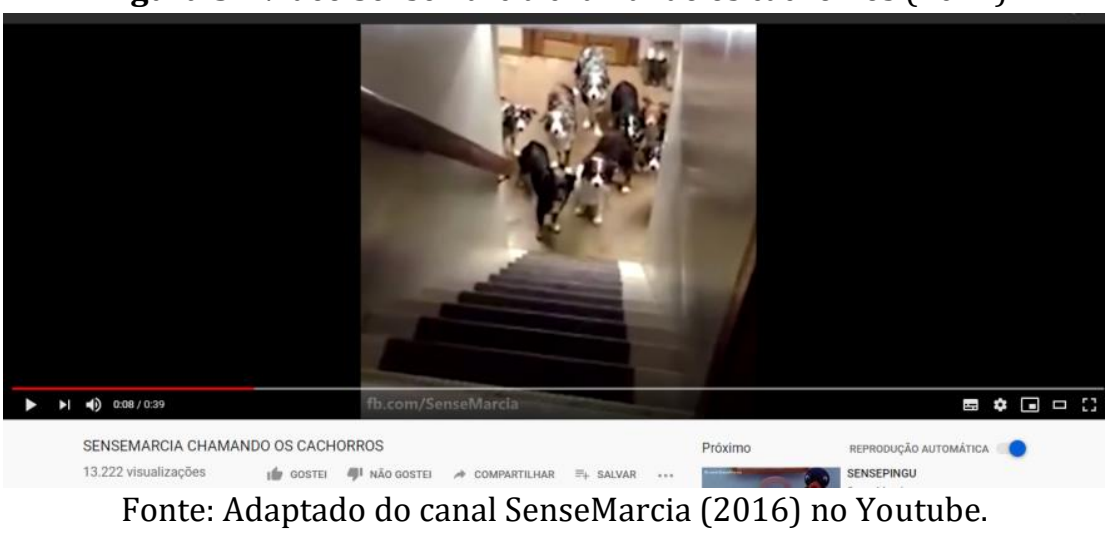

\footnotetext{
4 Santos reverenciados por cristãos católicos e identificados com a Umbanda e Candomblé. São Cosme e Damião foram dois irmãos gêmeos que, em vida, praticavam caridades como atendimentos médicos sem cobrar pelo serviço. São conhecidos por serem os santos protetores das crianças e, devido a isto, nas festas de comemoração é comum a oferenda de doces e distribuição de guloseimas para crianças.
} 
0 vídeo segue a mesma lógica até o fim, substituindo o áudio original por falas da astróloga. Aos 14 segundos ela diz "gnominho, gnominho", "bobona" e "defunto básico" (SENSEMARCIA..., 2017, doc. não paginado). A cada um desses chamamentos, há a impressão que os cachorros respondem, atendendo ao seu nome e subindo as escadas. É possível observar a utilização da estratégia de humor que Figueiredo (2012) denomina como teoria da incongruência, e refere-se à quebra do fluxo narrativo. Aqueles que assistem ao vídeo são surpreendidos pela voz de Márcia Fernandes e pelo conteúdo dos excertos inseridos no áudio.

É notável que o canal SenseMarcia (2016) opta por termos e frases que são característicos e estão presentes nas entrevistas e programas midiáticos que a terapeuta participa. Há diversos vídeos no Youtube em que a mesma ensina como atrair gnomos e outros seres mágicos para a casa, por meio de simpatias e outros rituais. Outro ponto a ser destacado é defunto básico, referência às insistentes dicas de como purificar energeticamente os ambientes que estariam contaminados por almas e espíritos. 0 discurso religioso é abordado por Fernandes de forma muito coloquial, a mesma trata sobre seres de outro mundo naturalmente, fato que pode despertar estranhamento nos que assistem, pois entra em conflito com o estereótipo de clérigos, pastores, gurus e líderes religiosos africanos ou de outras vertentes religiosas que tratam a sua religiosidade respeitosamente e com seriedade. Esta incongruência marca não somente o que é dito, mas também como é dito, despertando os sentidos de humor no vídeo.

A partir dos 25 segundos até o fim temos a voz de Márcia Fernandes dizendo "salmo 66", "sabonete de anil", "babaca" e "fofoqueira" respectivamente (SENSEMARCIA..., 2017, doc. não paginado). Novamente, os cachorros presentes no vídeo viral obedecem ao chamamento. A trajetória religiosa de Márcia Fernandes reflete-se no seu trabalho como terapeuta holística. A mesma participa de diversas vertentes e trata as mesmas em unicidade. Este aspecto é observado no recorte salmo 66, uma referência aos salmos bíblicos cristãos em consonância com o sabonete de anil, artefato muito utilizado por espiritualistas e praticantes de religiões de matriz africana para limpeza energética do corpo e ambientes. Essa bricolagem (HERVIEU-LÉGER, 2008) é utilizada em um movimento de causa e efeito. Para cada solicitação de ouvintes, telespectadores e clientes de Márcia, a mesma prescreve uma solução religiosa, como a leitura de um salmo, um banho de ervas, uma simpatia. Esse comportamento, tantos dos praticantes, como da terapeuta, é um sintoma social da modernidade, em que não há o interesse em apegar-se e submeter-se às 
coerções religiosas. O contato com o divino se dá de forma mágica, sem seguir doutrinas, quase como uma medicação de uso tópico.

Por fim, se destaca os excertos babaca e fofoqueira e estes seguem a mesma lógica de despertar efeitos de humor por entrar em conflito com a imagem compartilhada de líderes religiosos. Figueiredo (2012) também afirma que a superioridade ou o distanciamento entre o que é objeto de riso também é uma estratégia de humor. Ouvir uma pessoa que está em busca de aconselhamento e baseando as decisões acerca da própria vida nas respostas ríspidas e predições pessimistas de Márcia Fernandes é uma forma de fazer rir. Como já citado anteriormente, Figueiredo (2012) afirma que a ambivalência do "sentir pena" é sutil, e pode variar entre achar uma situação engraçada ou sentir remorso. No caso do vídeo, a graça deriva de as pessoas depositarem confiança e expectativas em receber boas notícias de uma pessoa que é conhecida por ser rude e indelicada. Dessa forma, esses aspectos sobressalientes da personalidade da terapeuta são utilizados pelo canal SenseMarcia, na tentativa de causar o riso por meio da mescla midiática. Isto posto, o canal faz uso de virais para entrar na lógica da midiatização (HJARVARD, 2014), obtendo maior alcance, engajamento e utilizando estrategicamente um vídeo conhecido por um grande público para que o conglomerado de mensagens faça sentido e surta efeitos de humor.

O terceiro e último vídeo chama-se Dua Lipa trazendo as NOVAS REGRAS do mundo espiritual (2017). Primeiramente, é preciso situar as leitoras e leitores que Dua Lipa é uma cantora Pop que ficou internacionalmente conhecida pela sua música New Rules. 0 videoclipe corresponde à história da música que pretende estabelecer três regras para evitar um amor não correspondido.

Figura 4 - Dua Lipa trazendo as NOVAS REGRAS do mundo espiritual (2017)

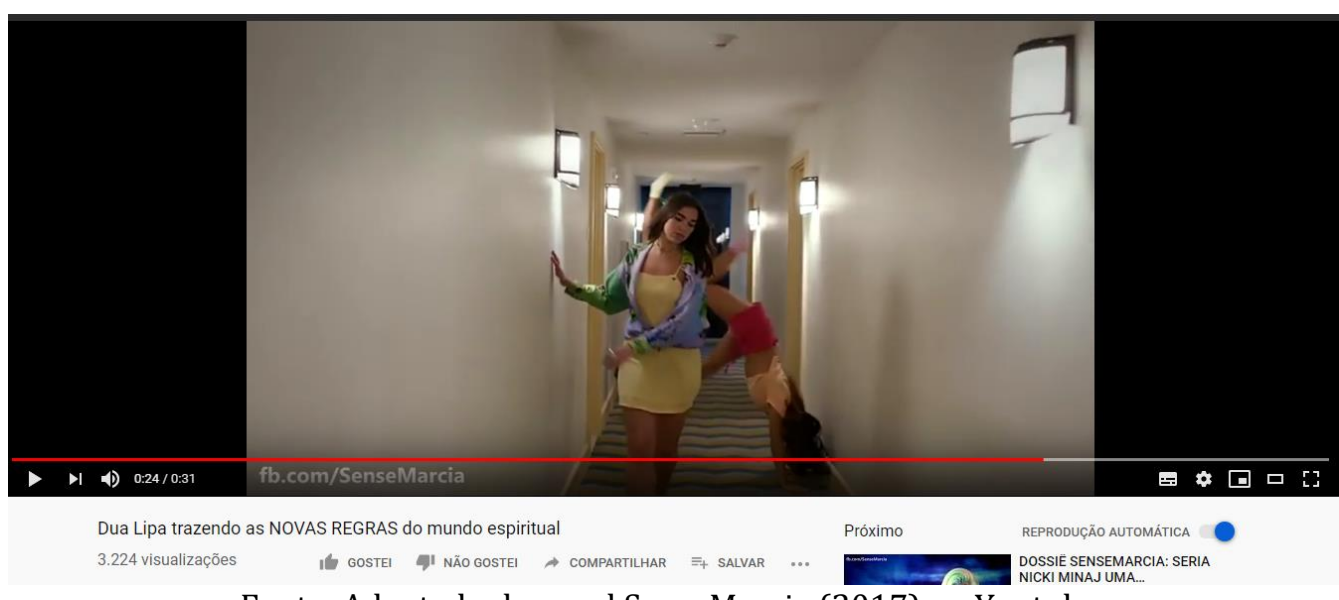

Fonte: Adaptado do canal SenseMarcia (2017) no Youtube. 
Assim como nos outros vídeos, o clipe da música é utilizado como base. Excertos de vídeos em que Márcia Fernandes aparece respondendo aos seus ouvintes em um programa de rádio são justapostos. No momento da música em que a cantora dita a primeira regra, não atender à chamada telefônica, o clipe é cortado para Márcia dizendo, aos cinco segundos, "Sabe aquela sua prima que liga só para falar desgraça? Desliga o telefone na cara dela." (DUA..., 2017, doc. não paginado). Em seguida, a música sugere a segunda regra, e novamente temos a substituição do clipe pela imagem de Márcia falando, aos dez segundos, "Pega a bíblia vai andando pela tua casa igual uma doida." (DUA..., 2017, doc. não paginado). E, por fim, quando chega o momento da terceira regra, aos 14seg., o excerto de vídeo da terapeuta diz "você não pode desejar aquilo que você não poder ter, para de ser doida" (DUA..., 2017, doc. não paginado). Assim, o vídeo segue até os 31 segundos com o videoclipe da música e algumas imagens, sem substituição de áudio, de Márcia Fernandes.

A incongruência (FIGUEIREDO, 2012) é a estratégia mais utilizada pelos vídeos do canal SenseMarcia (2016). Novamente, quem assiste é surpreendido pela sobreposição de vídeos e sentidos. As novas regras de relacionamentos são substituídas, como sugere o título, por regras do mundo espiritual. A primeira delas diz respeito a não atender ou envolver-se em conversas negativas. Segundo nova eristas e espíritas, o pensamento teria poder de atrair energias. Márcia reforça essa crença ao sugerir aos ouvintes não se envolverem em assuntos de desgraça, para que não atraiam o mesmo para as suas vidas. 0 mesmo vale para a terceira regra, em que a terapeuta aconselha aos ouvintes que não desejem aquilo que não podem conquistar, ou seja, não gastarem a própria energia com algo que não terá efeito. A quebra de expectativas, novamente, apresenta-se não apenas no que é dito, mas em como é dito. A prescrição da terapeuta é carregada por uma certa agressividade quando chama a ouvinte de "doida". Ou seja, um comportamento não condizente com uma pessoa que se denomina terapeuta. A segunda regra, por sua vez, converge ao conceito de bricolagem (HERVIEU-LÉGER, 2008) ao aconselhar aos ouvintes que utilizem a bíblia cristã, fazendo um mescla de recursos terapêuticos de diferentes religiões durante suas falas. Dessa forma, o canal SenseMarcia (2016) utiliza as características mais marcantes da personalidade da terapeuta como recurso humorístico. Nesse caso, realizando a paródia da música pop e ditando, com veemência, três regras religiosas para os seus ouvintes. 


\section{Considerações finais}

No percurso de construção desta pesquisa, foi articulado um aporte teórico que fosse suficiente para fundamentar e explicar as complexidades que o objeto possui e que não seria possível apenas no nível da empiria. O canal SenseMarcia (2016), devido ao seu caráter humorístico, talvez possa não parecer relevante ao nível de uma investigação sobre religião ou comunicação. Entretanto, o que notamos foi a utilização de uma vasta carga de referências simbólicas e religiosas que puderam ser explicadas pela visada da religião (HERVIEU-LÉGER, 2008) e da midiatização (SBARDELOTTO, 2017).

Assim como já mencionado, a modernidade causou inúmeras transformações para a humanidade. Em menos de dois séculos, presenciamos a passagem de uma sociedade dos meios para uma midiatizada (HJARVARD, 2014), e a nossa relação com a mídia estreitou-se a ponto de ela não apenas pautar, como também organizar a sociedade a partir de suas lógicas. Dentre essas transformações, a religião foi afetada e, consequentemente, teve de adaptar-se ao mundo midiatizado (SBARDELOTTO, 2017) modificando as formas de crer, os rituais, o contato com o divino. A procura por aconselhamento espiritual de Márcia Fernandes é um exemplo de como a religião, agora, circula pela mídia não mais apenas por meio de recursos institucionais como as missas, procissões, festas em terreiros, sessões espíritas.

Como foi possível observar na análise, o canal SenseMarcia aproveita a bricolagem (HERVIEU-LÉGER, 2008) feita pela astróloga Márcia Fernandes para direcionar o seu humor. Assim como a terapeuta espiritual faz um misto de referências religiosas, os proprietários do canal fazem uma fusão de referências midiáticas, misturando mídias e diferentes assuntos para compor suas estratégias de humor (FIGUEIREDO, 2012).

Com base na análise realizada, é possível afirmar que os ouvintes ou seguidores de Márcia Fernandes vão em busca de seus atendimentos, dicas e rituais na procura por orientações para a vida. Em um mundo marcado pelas incertezas, pelas possibilidades, pelas diversas ofertas de crenças, vão em busca de um espaço que forneça segurança (GIDDENS, 2002) e explicações do além-mundo. Esse local pode ser físico ou virtual. A midiatização da religião demonstra essa capacidade de agregar fiéis e construir comunidades a partir das ferramentas midiáticas, como redes sociais, podcasts, transmissão ao vivo de rituais de cada crença. 
E é nesse aspecto de busca por refúgio que o canal SenseMarcia encontra sua fonte de humor. A incongruência que há entre a imagem compartilhada de uma terapeuta ou representante religiosa e o comportamento indelicado e grosseiro de Fernandes, somado ao pessimismo e quebra de espectativas daqueles que procuram a mesma para tomar decisões e saber o futuro das suas vidas, é utilizado pelo canal por meio de colagens, sobreposições e montagens com outras mídias para compor as piadas postadas no Youtube.

Neste ambiente miditizado, o recorte do objeto de investigação, canal SenseMarcia (2016), possibilitou traçar inferências sobre o contexto social através dos meios de comunicação, conforme afirmam Assman, Quadros e Lopez (2014). Foi observado que a produção de sentidos, fruto da midiatização (HJAVARD, 2014), é operada com base nas novas configurações midiáticas. A própria capacidade de produzir um conteúdo a ser compartilhado nas redes sociais, bem como ter acesso por meio da internet e suas plataformas a conteúdos das mídias massivas, como televisão e rádio, e a realocação da prática religiosa compõem esse novo marco social em que mídia adquire uma centralidade. Desta forma, será cada vez mais frequente e intigada a fusão de assuntos divergentes e a as trocas epistemológicas, como é o caso do canal SenseMarcia (2016), que faz uso humor por meio de conteúdos da mídia tradicional, aliado a temas religiosos e utilizando as ferramentas de difusão digital.

\section{Financiamento}

Trabalho realizada com apoio financeiro da Coordenação de Aperfeiçoamento de Pessoal de Nível Superior (CAPES).

\section{Referências}

ASSMANN, Gabriela; QUADROS, Mirian; LOPEZ, Débora Cristina. Análise de Conteúdo nos nas pesquisas brasileiras em comunicação: aplicações e derivações do método. In: BARICHELLO, Eugênia Maria da Rocha; RUBLESCKI, Anelise (org.). Pesquisa em Comunicação: olhares e aborgens. Santa Maria: Facos, 2014.

BERGSON, Henri. 0 riso. Rio de Janeiro: Zahar, 1978.

DOG name calling. [S. l.: s. n.], 29 mar. 2017. 1 vídeo (ca. 1 min). Publicado pelo canal The Uplifting. Disponível em: https://www.youtube.com/watch?v=NLVJo2WegLo. Acesso em: 6 nov. 2019. 
DUA Lipa trazendo as novas regras do mundo espiritual. [S. l.: s. n.], 13 nov. 2017. 1 vídeo (ca. $1 \mathrm{~min}$ ). Publicado pelo canal SenseMarcia. Disponível em:

https://www.youtube.com/watch?v=b2ggR-HJYqc. Acesso em: 6 nov. 2019.

FAILARMY. [S. l.: s. n.], 5 jul. 2011. Canal no Youtube. Disponível em:

https://www.youtube.com/user/failarmy/featured. Acesso em: 5 nov. 2019.

FIGUEIREDO, Celso. Porque rimos: um estudo do funcionamento do humor na publicidade.

Comunicação e Sociedade, São Paulo, v. 33, n. 57, p. 171-198, 2012.

GIDDENS, Anthony. Modernidade e identidade. Rio de Janeiro: Zahar, 2002.

HERVIEU-LÉGER, Danièle. 0 peregrino e o convertido: a religião em movimento.

Petrópolis: Vozes, 2008.

HJARVARD, Stig. Midiatização: conceituando a mudança social e cultural. Matrizes, São Paulo, v. 8, n. 1, p. 21-44, 2014.

MÁRCIA Fernandes: home. [S. l.], 2018. Disponível em:

http://www.marciafernandes.com.br/site/. Acesso em: 22 jun. 2018.

MATA, María Cristina. De la cultura masiva a la cultura mediática. Diálogos de la comunicación, Lima, p. 80-91, 1999.

POR essa visão a Raven não esperava. [S. l.: s. n.], 13 nov. 2017. 1 vídeo (ca. 1 min). Publicado pelo canal SenseMarcia. Disponível em: https://www.youtube.com/watch?v=39zWoS-Vj4g. Acesso em: 1 jul. 2018.

SBARDELOTTO, Moisés. E o verbo se fez rede: religiosidades em reconstrução no ambiente digital. São Paulo: Paulinas, 2017.

SENSEMARCIA. [S. l.: s. n.], 25 ago. 2016. Canal no Youtube. Disponível em: https://www.youtube.com/channel/UCP6028ryG2gd4bHufV4k02w/featured. Acesso em: 29 ago. 2019.

SENSEMARCIA chamando os cachorros. [S. l.: s. n.], 13 nov. 2017. 1 vídeo (ca. 1 min). Publicado pelo canal SenseMarcia. Disponível em:

https://www.youtube.com/watch?v=UuerjLs_bjw. Acesso em: 6 nov. 2019.

\section{SenseMarcia: Humor and esoteric religiousity in the environment of the midiatized society}

\footnotetext{
Abstract

This paper aims to analyze the joint between humorous and religious content on the SenseMarcia Youtube channel, in order to identify what are the strategies used by SenseMarcia's
} 
channel to create humor connotations to the mediatized religious content created by astrologer Márcia Fernandes. To conduct the research, as a theoretical framework, authors Hjarvard (2014) and Sbardelotto (2017) were referenced to account for the notion of mediatization, Hervieu-Léger (2008) for the conceptualization of secularization. For the methodological analysis, three videos are analyzed by Content Analysis in conjunction with the propositions of humor categories by Figueiredo (2012). During the development of the research, it was observed that different religious and therapeutic mentions are used by the channel owners who perform a fusion of media references, combining media and different subjects to compose their strategies of conferring humorous effect.

\section{Keywords}

Humor. Midiatization. Religion. Esotericism. Multplatforms.

\section{Autor correspondente}

Aline Roes Dalmolin

dalmoline@gmail.com

\section{Como citar}

ROSA, Francys Albrecht da; DALMOLIN, Aline Roes. SenseMarcia: O humor e a religiosidade esotérica na ambiência esotérica da sociedade midiatizada. Intexto, Porto Alegre, n. 52, e-96057, jan./dez. 2021. DOI: http://dx.doi.org/10.19132/1807-8583202152.96057

Recebido em 31/08/2019

Aceito em 30/11/2019

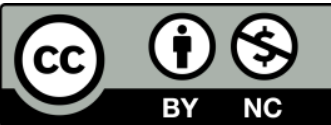

